\title{
Surface water sanitation and biomass production in a large constructed wetland in the Netherlands
}

\author{
Bastiaan G. Meerburg • Pieter H. Vereijken • \\ Willem de Visser · Jan Verhagen · Hein Korevaar • \\ Erik P. Querner · Arianne T. de Blaeij · Adrie van der Werf
}

Received: 18 September 2009/Accepted: 24 February 2010/Published online: 12 March 2010

(C) The Author(s) 2010. This article is published with open access at Springerlink.com

\begin{abstract}
In Western-Europe, agricultural practices have contributed to environmental problems such as eutrophication of surface and ground water, flooding, drought and desiccation of surrounding natural habitats. Solutions that reduce the impact of these problems are urgently needed. Common reed (Phragmites australis) is capable of sanitizing surface water and may function as green energy source because of its high productivity. Here, the results of an experiment in a constructed wetland in the Netherlands are presented where two different sanitation treatments were compared. Depending on the residence time and volume per unit area, reed is capable to reduce the total amount of nitrogen in the water with average
\end{abstract}

Pieter H. Vereijken: 1948-2007.

B. G. Meerburg $(\varangle) \cdot$ P. H. Vereijken ·

W. de Visser - J. Verhagen - H. Korevaar .

A. van der Werf

Plant Research International, Agrosystems Research, Wageningen University \& Research Centre, P.O. Box 616, 6700 AP Wageningen, The Netherlands e-mail: Bastiaan.Meerburg@wur.nl

\section{E. P. Querner}

Alterra, Centre for Water and Climate, Wageningen University \& Research Centre, P.O. Box 47, 6700 AA Wageningen, The Netherlands

A. T. de Blaeij

LEI, Wageningen University \& Research Centre,

P.O. Box 29703, 2502 LS The Hague, The Netherlands efficiencies from 32 to $47 \%$ and the total amount of phosphorous with $27-45 \%$. Although biomass production still varies largely between different parts of the constructed wetland, a rapid increase in biomass was observed since planting. Constructed wetlands with reed provide opportunities to improve water quality and reed produces enough biomass to serve as green energy source. Moreover, these wetlands also function as a flood water reservoir and are possibly advantageous for biodiversity. The optimal moment of reed harvesting depends on the goal of the owner. This moment should be chosen wisely, as it may have consequences for reed filter regeneration, biomass production, biodiversity, methane emission and water sanitation efficiency.

Keywords Reed Phragmites australis . Water sanitation - Biomass production . Water storage $\cdot$ Constructed wetlands

\section{Introduction}

A low-lying country like the Netherlands has to cope with numerous problems in its water management. With half of the country below sea level, flooding is always imminent (Meerburg and Van der Werf 2008). If climate changes, the challenges faced by both water managers and land users will only increase (Middelkoop et al. 2001; Van Koningsveld et al. 2008). Besides flooding risks, another important 
problem is surface water pollution. The European Water Framework Directive (EWFD, 2000/60/EC) obliges all EU member states to ensure that the quality of surface and ground waters reaches a high standard ('good ecological status') by the year 2015. This is important, as during the past decades, the main rivers forming the Dutch delta (Rhine, Waal, Scheldt, Meuse and IJssel) gradually became polluted with nutrients (Wendland et al. 2005) and industrial waste (Kooistra et al. 2001; Van Vliet and Zwolsman 2008). Agricultural practices have contributed to these problems: flood risks were increased by rapid water drainage, and excess in nutrients from fertilizers and manure polluted ground and surface water (Oenema et al. 1998; Huijser et al. 2004).

To find solutions for these problems a pilot study was started in 2006 at the Lankheet Estate near the village of Haaksbergen, Overijssel Province, the Netherlands $\left(52^{\circ} 07^{\prime} 49.20^{\prime \prime} \mathrm{N}, 6^{\circ} 42^{\prime} 59.73^{\prime \prime} \mathrm{E}\right)$. In this pilot project innovative approaches in land use are tested for their efficiency and feasibility for water management. The project aims to create a constructed wetland that combines different functions in order to show the benefits of such a multifunctional system. Combining functions is an important precondition when solving water problems (Van Koningsveld et al. 2008) and moreover, constructed wetlands might offer land owners (e.g., farmers) new opportunities to generate an income (Meerburg et al. 2009). At Lankheet, four functions are combined: surface water sanitation, periodic water retention in case of floods, biomass production for green energy, and nature conservation. It is investigated whether these functions can be combined ecologically and economically. In this article, we will focus on the results of surface water sanitation and production of biomass.

The constructed wetland was planted with reed (Phragmites australis). This crop can maintain its productivity under various water regimes allowing for temporary water storage and conservation. Nutrients that are taken up by the crop, are removed from the water when the reed is harvested annually (Verhoeven and Meuleman 1999; Toet et al. 2005). At the Lankheet estate, possibilities to use the biomass as source for green energy are further investigated. The pilot study also includes an assessment of the hydrological consequences of the constructed wetland (Querner and Mulder 2007) and the possible development of marsh forests (not presented in this paper).

\section{Materials and methods}

Description of the study area

Lankheet is an estate of about 500 hectares on sandy soils with both forests and farmland. The oldest relicts of irrigation systems at this estate date from the thirteenth and fourteenth centuries. Three irrigation meadows were constructed at the estate at the end of the nineteenth century. During the winter, nutrient rich brook water was used to irrigate the meadows to increase soil fertility. This old method was frequently applied in the higher regions of the Netherlands. It increased grass production, allowing three harvests per year. Moreover, the grass sod was kept frost free during the winter, resulting in an early start of the growing season in the spring. A sideeffect was that hazardous insects and moles were dispelled. However, the introduction of artificial fertilizers made these meadows obsolete.

The estate is located along a brook (called 'Buurserbeek') that has total length of $16.2 \mathrm{~km}$. This brook was used for transportation of goods (mainly wood) until about 1850 . Since that time, the main function of the brook has been water drainage, while at the end of the nineteenth and the early twentieth century it was also used for the irrigation purposes that were mentioned before. Similar to other brooks and many waterways in the Netherlands the Buurserbeek is currently eutrophied by run-off and leaching of nutrients from heavily fertilized farmlands upstream and from wastewater. Moreover, the brook has been canalized and its drainage is so powerful that it is causing desiccation in the surrounding areas. The water board in the region (Waterschap Rijn and IJssel) claims that for Dutch conditions water quality in the brook is average, and $\mathrm{N}$ (nitrogen), $\mathrm{Zn}$ (zinc), $\mathrm{Cu}$ (copper) exceed critical regional or national standards (Anonymous 2007).

\section{Experimental site}

The estate owners and the local water board agreed to extract water from the brook in 2005 and lead it to a 
field planted with reed. A water supply canal was especially excavated for this purpose.

A 5 ha field was transformed into six experimental reed filters (Fig. 1) surrounded by dikes. The six filters I-VI (ca. 0.5 ha each) have been planted with reed rhizomes in August 2005 (4/ $\mathrm{m}^{2}$; each $20-30 \mathrm{~cm}$ long). The inflow into the reed filters varied between 230 and $650 \mathrm{~m}^{3}$ day $^{-1}$.

The nutrient load in the water supply canal is constantly monitored by a sampling point. Moreover, the inflow of eutrophic brook water across the six reed filters is controlled by pumps, flow meters and samplers. The outflow is led through a network of water courses to restore the water table and ecology of the surrounding desiccated forests with "purified water". Each reed filter consists of three sections (a, b, and c, see Fig. 1), which are separated from each other by dikes.

For each reed filter, the water intake volume and water output are measured by flow meters and registered by a central computer. For every $100 \mathrm{~m}^{3}$ of water through flow a signal is given to the discharge-proportional sampler, which takes a sample of about $80 \mathrm{ml}$ and stores it in a cooled bottle.

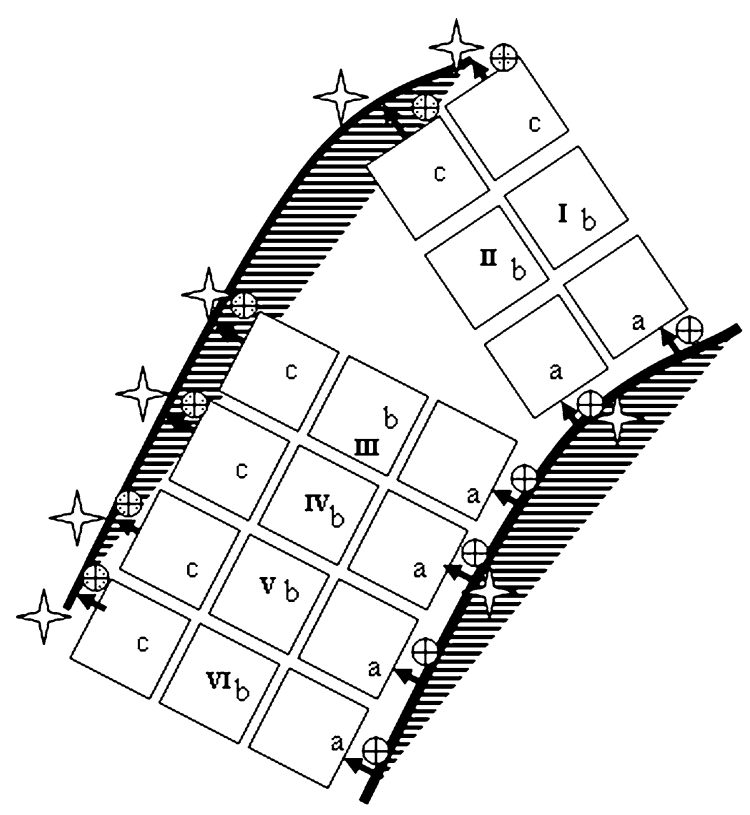

Fig. 1 Structure of the six reed filters. Each filter ( $I$ to $V I$ ) consists of three sections $(a-c)$. Circles represent flow meters, either input or output. Stars represent proportionate samplers
To assess the sanitation effect of the reed filters the brook water is sampled before the intake points and beyond the outlet. Every $24 \mathrm{~h}$ such a bottle is filled. After a week, output samples are mixed separately for every of the six reed filter. Input samples are only taken by two proportional samplers at filters II and IV and also mixed separately at the end of the week. Samples are analyzed for total amounts of phosphorous (TP) and nitrogen (TN), nitrate $(\mathrm{N}-\mathrm{NO} 3)$ and orthophosphate (ortho-P) with a spectrophotometer after chemical dilation in prefilled test tubes (Hach Lange, Tiel, The Netherlands).

After initial testing in 2006 and in early 2007, the study started late May 2007 and lasted seven consecutive weeks until late July. The difference between the chemical composition of the water at the input and the output was calculated in order to estimate nutrient removal and storage $\left(\mathrm{kg} \mathrm{ha}^{-1}\right.$ week $\left.{ }^{-1}\right)$ by the reed filters. Also the efficiency (\% removal) was estimated.

\section{Testing procedures}

Two different treatments were compared in order to find out how the best sanitation efficiency could be reached. During the first treatment, treatment A, the locks in the dikes between the sections in the reed filter were all open and the water that was pumped into a reed filter was allowed to stay in sections $\mathrm{a}, \mathrm{b}$ and $\mathrm{c}$ for $24 \mathrm{~h}$. This treatment was applied on reed filters I, III and V. During the second treatment, treatment $\mathrm{B}$, the locks in the dikes between sections a, $\mathrm{b}$ and $\mathrm{c}$ of the reed filter were closed and the water was pumped from section to section after it had been in the previous section for $6 \mathrm{~h}$. This treatment was applied on reed filters II, IV and VI. So, residence time per unit area was $24 \mathrm{~h}$ in treatment $\mathrm{A}$ and $6 \mathrm{~h}$ per unit area in treatment B. Consequently, there was water in all three sections simultaneously in reed filters under treatment $\mathrm{A}$ and only in one section per time period in those filters under treatment B. The reader should thus be aware that the size of the unit area and the volume of water differed between treatments.

For each treatment, the average concentration of the inlet was compared with the average concentration of the outlet using a two-sided unpaired $t$ test. This comparison was made for TP (total phosphorus), 
TN (total nitrogen), N-NO3 (nitrate), and ortho-P (orthophosphate).

Biomass was sampled at 72 locations in the first year after construction, September 2006, in order to determine the dry weight $\left(\mathrm{g} \mathrm{m}^{-2}\right)$. In 2007 the biomass production of the six reed filters was measured five times via destructive harvesting and indirectly by using the CropScan ${ }^{\circledR}$ multispectral radiometer. The indirect method by the Crop Scan was applied in order to assess the variance in standing crop within and between sections more accurately. The CropScan measures the reflectance from the plants in specific bandwidths, which are used to calculate the Weighted Difference Vegetation Index $(\mathrm{WDVI})$ as follows: WDVI $=\mathrm{IR}-\left(\mathrm{IR}_{\mathrm{s}} / \mathrm{GR}_{\mathrm{s}}\right) \times$ $\mathrm{GR}(\%)$, where IR and GR are the infrared and green reflectance of the crop and $I_{\mathrm{s}}$ and $\mathrm{GR}_{\mathrm{s}}$ are the infrared and the green reflectance of the bare soil (Uenk et al. 1992). The WDVI-measurements were used to estimate above ground biomass.

During the initial four biomass measurements two reed sections of each reed filter were sampled (see Table 2). During the fifth biomass measurement in September 2007 all three sections of each reed filter were sampled (three samples/section). The samples were dried and the dry weight $\left(\mathrm{g} \mathrm{m}^{-2}\right)$ was determined. The reed in filter II was harvested in September 2007, the reed in all other reed filters was allowed to die-back and was harvested in March
2008. Reed filter II was harvested in September in order to analyze re-growth capabilities of the reed and to analyze its nutrient content (data not presented here).

\section{Experimental results}

Water quality

Nutrient concentrations in the water supply canal were continuously monitored. The nutrient concentrations at the inlet of the reed filters did not differ between the treatments A and B (data not shown).

With increasing nutrient load $\left(\mathrm{kg} \mathrm{ha}^{-1}\right.$ week $\left.^{-1}\right)$ removal of nutrients increased linearly (Figs. 2, 3, 4, 5). Except for Ortho-P, removal efficiencies of TN, $\mathrm{TP}$, and $\mathrm{N}-\mathrm{NO}_{3}$ were significantly higher in treatment A (Figs. 2, 3, 4, 5; Table 1). The treatments significantly reduced nutrient concentrations from the inflow to the outflow (Table 2). The nutrient removal efficiencies of different reed filters during a 7-week period are presented in Table 1. More water was pumped out of reed filters IV, V, and VI than was pumped into these filters (see also Table 1). The reason for this was the emergence of seepage in these filters. Unfortunately it was impossible to determine the quality of this seepage water, which is probably caused by ground water flows. Water input exceeded
Fig. 2 Comparison of the removal capacity of nitrogen $(\mathrm{N})$ and the efficiency of both treatments (treatment A: squares, treatment $\mathrm{B}$ : circles)
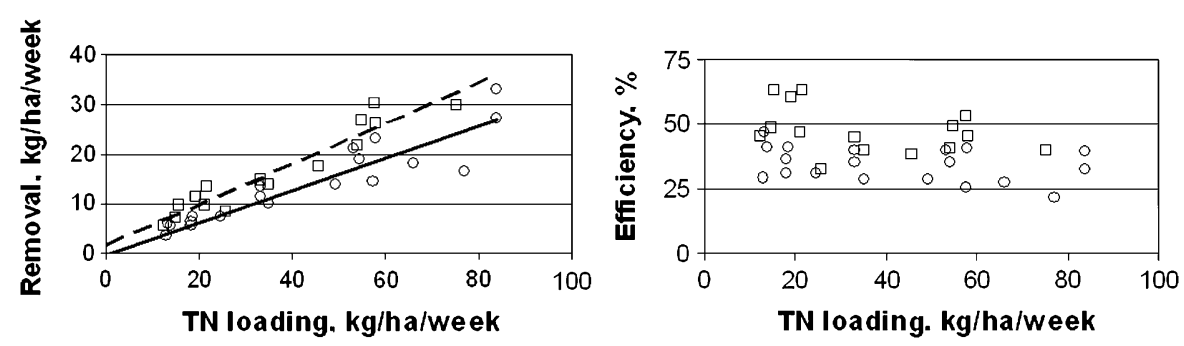

Fig. 3 Comparison of the removal capacity of nitrate (N-NO3) and the efficiency of both treatments (treatment A: squares, treatment B: circles)
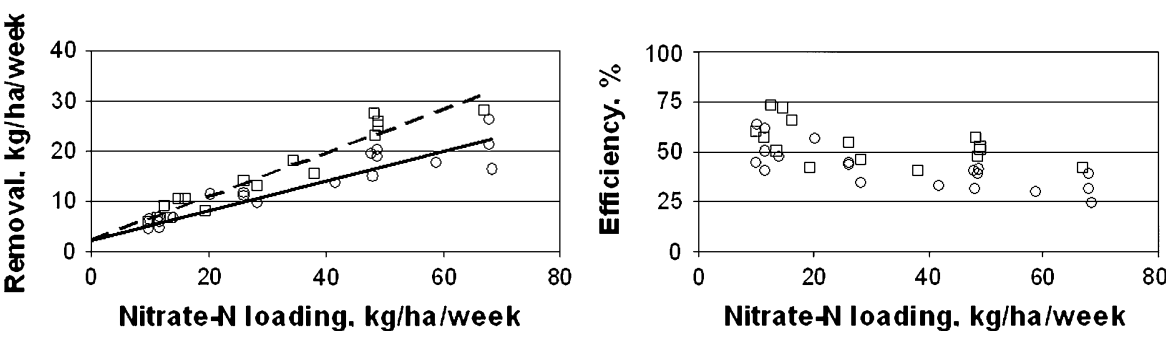
Fig. 4 Comparison of the removal capacity of phosphate $(\mathrm{P})$ and the efficiency of both treatments (treatment A: squares, treatment $\mathrm{B}$ : circles)
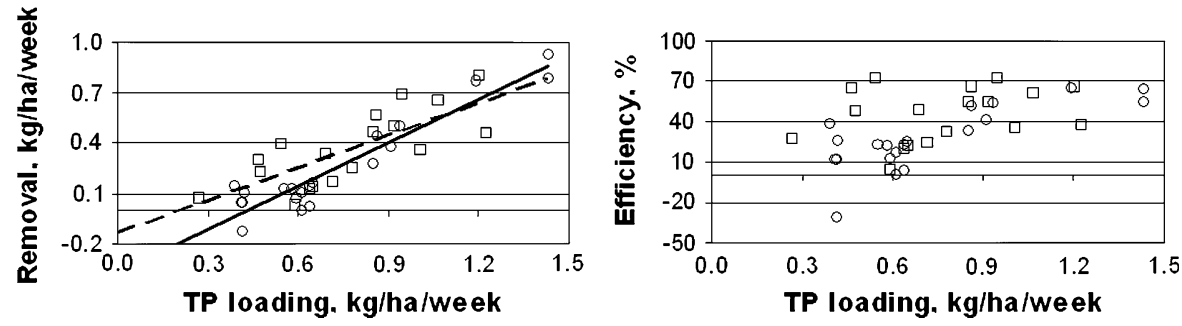

Fig. 5 Comparison of the removal capacity of orthophosphate (ortho-P) and the efficiency of both treatments (treatment A: squares, treatment $\mathrm{B}$ : circles)

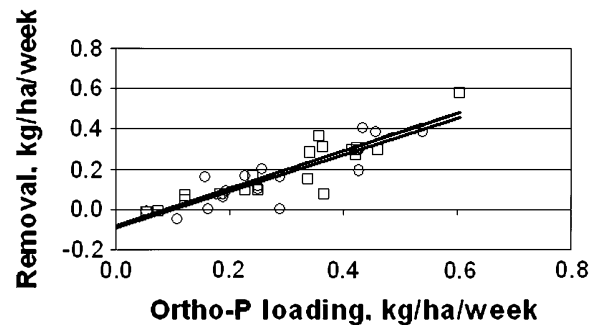

Table 1 Efficiencies of the different reed filters in the removal of nutrients from the water $(\mathrm{TP}=$ total phosphorous, $\mathrm{TN}=$ total nitrogen)

\begin{tabular}{|c|c|c|c|c|c|c|c|}
\hline $\begin{array}{l}\text { Reed } \\
\text { filter }\end{array}$ & Treatment & $\begin{array}{l}\text { Water in } \\
\left(\mathrm{m}^{3} \text { week }^{-1}\right)\end{array}$ & $\begin{array}{l}\text { Water out } \\
\left(\mathrm{m}^{3} \text { week }^{-1}\right)\end{array}$ & $\begin{array}{l}\text { Efficiency } \\
\operatorname{TP}(\%)\end{array}$ & $\begin{array}{l}\text { Efficiency Ortho- } \\
\text { P }(\%)\end{array}$ & $\begin{array}{l}\text { Efficiency } \mathrm{TN} \\
(\%)\end{array}$ & $\begin{array}{l}\text { Efficiency } \\
\mathrm{N}-\mathrm{NO}_{3}(\%)\end{array}$ \\
\hline I & A & 3,040 & 2,949 & 60 & 79 & 42 & 47 \\
\hline II & B & 2,913 & 2,840 & 46 & 58 & 31 & 36 \\
\hline III & A & 2,812 & 2,385 & 49 & 52 & 55 & 63 \\
\hline IV & B & 3,148 & 3,318 & 23 & 35 & 39 & 50 \\
\hline $\mathrm{V}$ & A & 3,405 & 3,460 & 26 & 27 & 45 & 52 \\
\hline VI & $\mathrm{B}$ & 3,070 & 3,515 & 14 & 30 & 26 & 33 \\
\hline \multicolumn{2}{|c|}{$\begin{array}{l}\text { Avg. efficiency } \\
\text { treatment A (\%) }\end{array}$} & $3086^{\mathrm{a}}$ & $2931^{a}$ & $45^{\mathrm{a}}$ & $53^{\mathrm{a}}$ & $47^{\mathrm{a}}$ & $54^{\mathrm{a}}$ \\
\hline \multicolumn{2}{|c|}{$\begin{array}{l}\text { Avg. efficiency } \\
\text { treatment B }(\%)\end{array}$} & $3050^{\mathrm{a}}$ & $3243^{\mathrm{a}}$ & $27^{\mathrm{b}}$ & $41^{\mathrm{a}}$ & $32^{\mathrm{b}}$ & $40^{\mathrm{b}}$ \\
\hline
\end{tabular}

Means with the same letter were not significantly different $(P>0.05)$

Table 2 Average concentrations \pm SE $(n=38)$ for in- and outflow of the reed filters

\begin{tabular}{lcc}
\hline Nutrient & Concentration in $\mathrm{mg}^{-1}$ & Concentration out $\mathrm{mg}^{-1}$ \\
\hline $\mathrm{TP}$ & $0.106^{\mathrm{a}} \pm 0.006$ & $0.06^{\mathrm{b}} \pm 0.003$ \\
Ortho-P & $0.042^{\mathrm{a}} \pm 0.004$ & $0.016^{\mathrm{b}} \pm 0.002$ \\
$\mathrm{TN}$ & $5.36^{\mathrm{a}} \pm 0.36$ & $3.32^{\mathrm{b}} \pm 0.27$ \\
$\mathrm{~N}-\mathrm{NO}_{3}$ & $4.48^{\mathrm{a}} \pm 0.33$ & $2.53^{\mathrm{b}} \pm 0.24$
\end{tabular}

Means with the same letter were not significantly different $(P>0.05)$

that of water output in the other reed filters, presumably caused by evaporation and/or infiltration.
However, also in the other filters the emergence of seepage could not be excluded.

\section{Biomass productivity}

Biomass production increases rapidly over the years. On average, standing crop in September 2006 based on reflectance measurements was $221 \mathrm{~g} \mathrm{~m}^{-2}$. One year later, at the end of September 2007, standing crop increased to an average of $903 \mathrm{~g} \mathrm{~m}^{-2}$. Clearly, 2 years after transplanting rhizomes, still quite some variation in standing crop occurs (Fig. 6). 
Fig. 6 Box and Whisker Plot that demonstrates differences in estimated biomass between different reed sections in 2007. Boxes indicate 25th, 50th and 75th percentiles

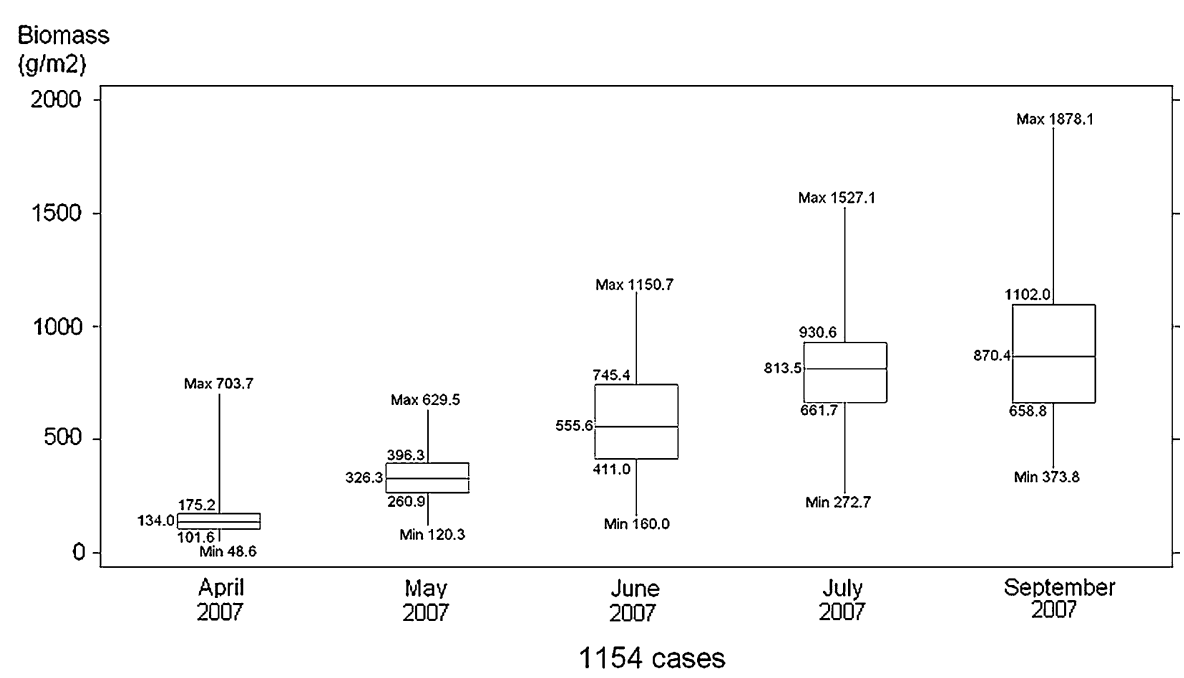

\section{Discussion}

In this study, common reed (Phragmites australis) was used to create a multifunctional system that combines surface water sanitation, water storage and green energy production. The results so far are promising: the soil-reed-microbe system is capable of filtering significant amounts of nutrients from the water and biomass production is considerable.

The current ecological status of Dutch surface waters is constantly monitored in line with the demands of the European Water Framework Directive (EWFD, 2000/60/EC). New targets are to be set to reach the "good status". In 2009 the EU member states should finish a first policy plan for each international river basin district containing a "programme of measures" to reach the EFWD-goals.

Critical threshold values for TN and TP are not yet defined for the surface water body "Buurserbeek". This is a task for the province of Overijssel, where the Lankheet estate is located. Preliminary critical threshold values for a good ecological perspective were recently provided: $2.5-4 \mathrm{mg} \mathrm{N} / 1$ and $0.12-$ $0.14 \mathrm{mg} \mathrm{P} / \mathrm{l}$ (Anonymous 2008).

Our results demonstrate that the critical value for $\mathrm{P}$ is not problematic, while for $\mathrm{N}$ this still remains questionable. The residence time (time that the water remains in the filters) seems to be very important for the efficiency of reed sanitation, a conclusion shared by others (Schulz et al. 2003). Table 1 and Figs. 2, 3, 4, 5 show that with increasing residence time sanitation efficiency also increases, especially for
TN. In a pilot lasting 1-week residence time was increased to $72 \mathrm{~h}$ in three filters. Now efficiencies of $54,61,80$, and $85 \%$ were obtained for TP, Ortho-P, $\mathrm{TN}$, and $\mathrm{N}-\mathrm{NO}_{3}$, respectively. Residence time is currently being investigated more in detail. Furthermore, Figs. 2, 3, 4, 5 clearly indicate a non-saturating linear relationship between nutrient load and nutrient removal. This suggests that soil-plant-microbe system is not saturated and is probably capable to deal with higher nitrogen and phosphorous loads. Nitrogen removal in constructed wetlands depend on the combination of factors, such as denitrification, plant uptake and volatilization. Many of these processes are $\mathrm{pH}$ dependent (Vymazal 2007).

At Lankheet, the average $\mathrm{pH}$ of the reed filter soils was measured in 2006, 2007, and 2008 and the mean results varied between 6.1 and 6.2, whereas the $\mathrm{pH}$ of the surface water was around 7.0. But $\mathrm{pH}$ is only one soil characteristic. Other soil properties (such as carbon, redox potential, DO (dissolved oxygen) level at the soil water interface) are also important for the efficient removal of nutrients from the water (Sooknah and Wilkie 2004). Among others, these properties will be analyzed the forthcoming years.

The loading rates for $\mathrm{TN}$ and $\mathrm{TP}$ in this system are considerably lower compared to those of constructed wetlands for wastewater treatment (Vymazal 2007). This is due to the fact that for surface water sanitation high volumes of water with a relatively low concentration of $\mathrm{N}$ and $\mathrm{P}$ have to be sanitized. However, this means that in order to sanitize surface water large areas next to surface water bodies are required. We 
have calculated the area that is needed to compensate for the yearly P-load in the Netherlands (7,000 tons P), assuming an efficiency of 50\%. About 150,000 ha of constructed wetlands with reed would be needed in the Netherlands in order to meet the EWFD-targets.

Reed is a highly productive crop (Vymazal 2005), with documented annual productivities varying between 10 and $50 \mathrm{t} \mathrm{ha}^{-1}$. Assuming biomass productivity of $25 \mathrm{t} \mathrm{ha}^{-1}, 150,000$ ha (about $5 \%$ of the total agricultural land available) could potentially produce a total of 3,750,000 t of reed biomass. This corresponds to an amount of about 64 PJ thermic green energy, under the precondition that this quantity of reed can be used economically and technically. This is a considerable potential and is equivalent to approx. $3 \%$ of the total expected energy demand of the Netherlands in 2030. Two years after planting average productivity was around $9 \mathrm{t} \mathrm{ha}^{-1}$, with a high variance (Fig. 6). However, Fig. 6 also shows that $25 \%$ of the samples had a higher productivity than $11 \mathrm{t} \mathrm{ha}^{-1}$, with the highest value of approx. $19 \mathrm{t} \mathrm{ha}^{-1} 2$ years after planting. Generally, it takes up to 4 years for $P$. australis to reach maximum standing crop (Vymazal and Kropfelová 2005), so we may assume that in our case maximum standing crop is by far not reached yet.

Choosing the moment of harvesting may have important consequences for the soil-plant-microbe system, especially on aspects as nutrient-removal, methane emission, filter regeneration and biomass production. Harvesting times need to be optimized in order to combine the different functions as water sanitation, biomass production and biodiversity goals.

In order to remove the maximum amount of nutrients out of the soil-plant-microbe system, harvesting should start before re-translocation of nutrients to the root system occurs (late summer). It is known that this can substantially contribute to the nutrient removal capacity of the wetland (Brix 1994; Kadlec and Knight 1996; Verhoeven and Meuleman 1999). Another advantage is that in this period standing crop is at its optimum (high energy content), the reed is still vital and methane production is limited (Sorrell and Boon 1994; Sorrell et al. 1997; Picek et al. 2007). However, when nutrients are still located in the plant when harvested, high concentrations of nutrients in the biomass may have corrosive effects on the energy processing plant. More importantly, plant re-growth in the next year may be lower (Meuleman et al. 2002). The reed at Lankheet was partly harvested in
September 2007, but the major part was harvested in early March 2008. Re-growth rates of reed in the filters that were mown in early March 2008 seemed quicker than the filter that was mown in September 2007 (data not shown). However, maximum biomass productivity was difficult to interpret because of a tremendous hail storm in June 2008. Conversely, mowing in February may also have several disadvantages. It may lead to less biomass production due to loss of foliage (and thus lower energy content) and lower water sanitation efficiencies in the long term.

For maximum biodiversity, mowing should probably take place at the end of February/early March. Mowing in August or in September/October can have an undesirable effect on the biodiversity as birds, insects and small mammals will use reed as cover during winter (Huijser et al. 2001, 2004; Schmidt et al. 2005).

Here, we have demonstrated that constructed wetlands can effectively contribute to the reduction of nutrients in the surface water and that Phragmites australis is capable to produce good amounts of biomass within a few years after the start of the project. The coming years biomass harvest times will be further optimized according to the functions that were mentioned earlier.

Acknowledgments The multifunctional constructed wetland Lankheet is financially supported by the Province of Overijssel, Water Board Rijn \& IJssel, the European Union, the Ministry of Agriculture, Nature and Food Quality and the national innovation fund for water management (Stichting Leven met Water). Their support is gratefully acknowledged.

Open Access This article is distributed under the terms of the Creative Commons Attribution Noncommercial License which permits any noncommercial use, distribution, and reproduction in any medium, provided the original author(s) and source are credited.

\section{References}

Anonymous (2007) Gebiedsrapportage KRW: Waterlichaam Buurserbeek 2007. Waterschap Rijn \& IJssel, Doetinchem, p 28

Anonymous (2008) Kwaliteit voor later: Ex ante evaluatie Kaderrichtlijn Water. Planbureau voor de Leefomgeving, Bilthoven, p 212

Brix H (1994) Functions of macrophytes in constructed wetlands. Water Sci Technol 29:71-78

Huijser MP, Meerburg BG, Voslamber B, Remmelzwaal AJ (2001) Mammals benefit from reduced ditch cleaning frequency in an agricultural landscape. Lutra 44:23-40 
Huijser MP, Meerburg BG, Holshof G (2004) The impacts of ditch cuttings on weed pressure and crop yield in maize. Agric Ecosyst Environ 102:197-203

Kadlec RH, Knight RL (1996) Treatment wetlands. CRC Press, Boca Raton

Kooistra L, Leuven R, Nienhuis PH, Wehrens R, Buydens LMC (2001) A procedure for incorporating spatial variability in ecological risk assessment of Dutch River floodplains. Environ Manag 28:359-373

Meerburg BG, Van der Werf A (2008) Man-made wetlands with combined functions: surface water sanitation, water storage and biomass production for energy, $\mathrm{p}$ 123. In: Speller P, Teixeira de Sousa Júnior P (eds) Eighth intecol international wetlands conference: big wetlands, big concerns. Federal University of Mato Grosso \& Pantanal Research Centre (CPP), Cuiabá

Meerburg BG, Korevaar H, Haubenhofer DK, Blom-Zandstra M, Van Keulen H (2009) The changing role of agriculture in Dutch society. J Agri Sci 147:511-521

Meuleman AFM, Beekman JP, Verhoeven JTA (2002) Nutrient retention and nutrient-use efficiency in Phragmites australis stands after wastewater application. Wetlands 22:712-721

Middelkoop H, Daamen K, Gellens D, Grabs W, Kwadijk JCJ, Lang H, Parmet BWAH, Schädler B, Schulla J, Wilke K (2001) Impact of climate change on hydrological regimes and water resources management in the Rhine basin. Clim Change 49:105-128

Oenema O, Boers PCM, Van Eerdt MM, Fraters B, Van der Meer HG, Roest CWJ, Schröder JJ, Willems WJ (1998) Leaching of nitrate from agriculture to groundwater: the effect of policies and measures in the Netherlands. Environ Poll 102:471-478

Picek T, Cízková H, Dusek J (2007) Greenhouse gas emissions from a constructed wetland-plants as important sources of carbon. Ecol Eng 31:98-106

Querner EP, Mulder HM (2007) Hydrological analysis for meeting climate change effects and European water framework directive targets. J Water Land Dev 11:59-69

Schmidt MH, Lefebvre G, Poulin B, Tscharntke T (2005) Reed cutting affects arthropod communities, potentially reducing food for passerine birds. Biol Conserv 121:157-166

Schulz C, Gelbrecht J, Rennert B (2003) Treatment of rainbow trout farm effluents in constructed wetland with emergent plants and subsurface horizontal water flow. Aquaculture 217:207-221

Sooknah RD, Wilkie AC (2004) Nutrient removal by floating aquatic macrophytes cultured in anaerobically digested flushed dairy manure wastewater. Ecol Eng 22:27-42

Sorrell BK, Boon PI (1994) Convective gas flow in Eleocharis sphacelata $\mathrm{R}$. Br.: methane transport and release from wetlands. Aquat Bot 47:197-212

Sorrell BK, Brix H, Schierup H-H, Lorenzen B (1997) Dieback of Phragmites australis: influence on the distribution and rate of sediment methanogenesis. Biogeochemistry 36:173-188

Toet S, Bouwman M, Cevaal A, Verhoeven JTA (2005) Nutrient removal through autumn harvest of Phragmites australis and Thypha latifolia shoots in relation to nutrient loading in a wetland system used for polishing sewage treatment plant effluent. J Environ Sci Health A 40:1133-1156

Uenk D, Bouman BAM, Kasteren HWJ (1992) Reflectiemetingen aan landbouwgewassen: handleidingen voor het meten van gewasreflectie. Cabo-DLO, Wageningen, p 56

Van Koningsveld M, Mulder JPM, Stive MJF, VanderValk L, VanderWeck AW (2008) Living with sea-level rise and climate change: a case study of the Netherlands. J Coast Res 24:367-379

Van Vliet MTH, Zwolsman JJG (2008) Impact of summer droughts on the water quality of the Meuse river. J Hydrol 353:1-17

Verhoeven JTA, Meuleman AFM (1999) Wetlands for wastewater treatment: opportunities and limitations. Ecol Eng $12: 5-12$

Vymazal J (2005) Horizontal sub-surface flow and hybrid constructed wetlands systems for wastewater treatment. Ecol Eng 25:478-490

Vymazal J (2007) Removal of nutrients in various types of constructed wetlands. Sci Total Environ 380:48-65

Vymazal J, Kropfelová L (2005) Growth of Phragmites australis and Phalaris arundinacea in constructed wetlands for wastewater treatment in the Czech Republic. Ecol Eng 25:606-621

Wendland F, Bogena H, Goemann H, Hake JF, Kreins P, Kunkel R (2005) Impact of nitrogen reduction measures on the nitrogen loads of the river Ems and Rhine (Germany). Phys Chem Earth 30:527-541 